\title{
PENGARUH TERAPI SPIRITUAL EMOTIONAL FREEDOM TECHNIQUE (SEFT) TERHADAP DEPRESI PADA PASIEN GAGAL GINJAL KRONIS
}

\author{
Setianingsih ${ }^{1}$, Tri Rahayuningsih ${ }^{2}$, Nur Wulan Agustina ${ }^{3}$ \\ ${ }^{1,3}$ Stikes Muhammadiyah Klaten \\ ${ }^{2}$ RSU PKU Muhammadiyah Klaten \\ Email:sw4228@gmail.com
}

\begin{abstract}
ABSTRAK
Pasien gagal ginjal yang menjalani hemodialisis seringkali mengalami depresi, akibat perasaan sedih memikirkan penyakit yang diderita yang tidak kunjung sembuh, adanya efek samping dari terapi hemodialisis, dan memikirkan banyaknya biaya pengobatan yang harus dikeluarkan. Salah satu terapi untuk mengatsi perasaan depresi pada pasien gagal ginjal dengan terapi hemodialisa dapat diberikan Spiritual Emotional Freedom Technique (SEFT). Tujuan dari penelitian ini adalah untuk mengetahui pengaruh pemberian Spiritual Emotional Freedom Technique (SEFT) dalam menurunkan tingkat depresi pada pasien gagal ginjal dengan terapi hemodialisa. Penelitian ini menggunakan desain pre experiment. Jumlah sampel penelitian sebanyak 10 pasien gagal ginjal yang menjalani hemodialisis di RSU PKU Muhammadiyah Delanggu Klaten. Alat pengumpulan data menggunakan Beck Depression Inventory (BDI). Intervensi berupa Spiritual Emotional Freedom Technique (SEFT) diberikan kepada semua responden. Yang kemudian dibandingkan tingkat depresi pre dan post terapi SEFT. Teknik analisis data menggunakan analisis univariat dan bivariat dengan uji statistik Paired t-test. Hasil penelitian diperoleh: (1) Usia pasien sebagian besar berusia antara 45-58 tahun (70\%), dan termasuk usia pertengahan memasuki periode lanjut usia; (2) Berdasarkan jenis kelamin, hampir seluruhnya adalah laki-laki (90\%); (3) Tingkat pendidikan pasien sebagian besar lulus SLTA sederajat (30\%) dan lulus perguruan tinggi (30\%); 94) Jenis pekerjaan pasien sebagian besar adalah buruh (40\%), PNS/pensiunan (20\%), dan tidak bekerja (20\%); 95) Seluruh pasien menjalani hemodialisis dalam kurun waktu kurang dari 2 tahun (100\%). Hasil uji Paired T-test antara skor pre test dan post test diperoleh angka $p$ value $=0,001<0,05$ yang menunjukan ada pengaruh signifikan. Kesimpulan penelitian ini adalah terapi SEFT dapat menurunkan tingkat tingkat deperesi pasien gagal ginjal yang menjalani hemodialisis.
\end{abstract}

Kata kunci : Gagal ginjal, Hemodialisis, Depresi, terapi SEFT

\section{ABSTRACT}

Kidney failure patients undergoing hemodialysis often experience depression, as a result of feeling sad thinking about their illness that does not go away, the side effects of hemodialysis therapy, and thinking about the large amount of medical expenses that must be incurred. One of the therapies to overcome feelings of depression in kidney failure patients with hemodialysis therapy can be given the Spiritual Emotional Freedom Technique (SEFT). The purpose of this study was to determine the effect of Spiritual Emotional Freedom Technique (SEFT) in reducing depression levels in patients with renal failure with hemodialysis therapy. This study used a pre experimental design. The number of 
research samples were 10 patients with kidney failure undergoing hemodialysis at PKU Muhammadiyah Delanggu Klaten Hospital. The data collection tool uses the Beck Depression Inventory (BDI). Intervention in the form of Spiritual Emotional Freedom Technique (SEFT) was given to all respondents. Which then compared the depression levels pre and post SEFT therapy. The data analysis technique used univariate and bivariate analysis with Paired t-test statistical test. The results obtained: (1) Most of the patients aged between 45-58 years (70\%), and included middle age entering the elderly period; (2) Based on gender, almost all were men (90\%); (3) Most of the patients have graduated from high school (30\%) and college (30\%); 94) Most of the patient's occupations are labor (40\%), civil servants / retirees (20\%), and not working (20\%); 95) All patients underwent hemodialysis in less than 2 years (100\%). The results of the Paired T-test between the pre-test and post-test scores obtained the $p$ value $=0.001<0.05$, which indicates a significant effect. The conclusion of this study is that SEFT therapy can reduce the level of depression in kidney failure patients undergoing hemodialysis.

Keywords: Kidney failure, hemodialysis, depression, SEFT 


\section{LATAR BELAKANG}

Penyakit Ginjal Kronik merupakan gangguan fungsi ginjal progresif dan tidak dapat sembuh kembali, dan membutuhkan pengganti ginjal. Ketika seseorang menderita PGK, pasien harus mendapatkan terapi seperti hemodialisis, atau transplantasi ginjal. Hemodialisis adalah terapi pengganti faal ginjal yang bertujuan untuk mengeluarkan sisa-sisa protein dan koreksi gangguan keseimbangan air dan elektrolit antara kompartemen darah pasien dengan kompartemen larutan dialisat melalui selaput (membrane) semipermeabel yang bertindak sebagai ginjal buatan (Sudoyo dkk, 2010).

Tahun 2010 Cengic (2010) melakukan penelitian dan mendapati prevalensi depresi dengan skor BDI > 11 mencapai 51\% pada pasien gagal ginjal. Prevalensi penderita penyakit ginjal kronik berdasarkan Indonesia Renal Registry pada tahun 2008 yaitu sekitar 200-250 per satu juta penduduk dan yang menjalani hemodialisis mencapai 2.260 orang. Jumlah ini meningkat dari tahun sebelumnya, dimana pasien hemodialisis pada tahun 2007 berjumlah 2.148 orang (Republikasi.co.id, 2011). Kaunang dalam Darwis pada tahun 2002 mendapati depresi pada pasien gagal ginjal terminal sebanyak 47,6 \% (Darwis, 2012).

Kondisi afektif yang negatif pada pasien gagal ginjal juga seringkali bertumpang tindih gejalanya dengan gejala-gejala pasien penyakit ginjal kronik yang mengalami uremia seperti iritabilitas, gangguan kognitif, ensefalopati, akibat pengobatan atau akibat hemodialisis yang kurang maksimal. Pendekatan psikodinamik pada gangguan depresi adalah suatu kondisi yang berhubungan dengan hilangnya sesuatu di dalam diri manusia tersebut (Andri, 2013).

Sungguh sulit bagi seseorang untuk dapat menerima kenyataan bahwa dirinya harus menjalani hemodialisis seumur hidup dengan proses yang berjalan selama 4-5 jam setiap kali tindakan hemodialisis. Hal ini dapat menimbulkan kejenuhan, sehingga dibutuhkan pendamping untuk memotivasi selama menjalani terapi hemodialisis (Tezel dkk, 2011). Pasien hemodialisis banyak mengalami masalah psikososial, seperti depresi, kecemasan, kesepian, isolasi sosial, putus asa, dan tidak berdaya. Semua hal itu merupakan masalah psikososial yang dapat meningkatkan kebutuhan pasien untuk mendapatkan perawatan holistik, yaitu termasuk perhatian dalam lingkungan dan mendapatkan dukungan dari keluarga. Jika pasien hemodialisis dirawat dan didukung sepenuhnya oleh keluarga, maka masalah psikososial ini bisa dicegah atau diminimalisir (Ahkari dkk, 2014).

Depresi merupakan permasalahan psikiatri terbanyak pada pasien yang menjalani hemodialisis (Saeed dkk, 2012) Gejala depresi terdapat pada 30\% pada pasien yang menjalani hemodialisis. Gejala depresi ini ber-hubungan dengan peningkatan mortalitas dan penurunan kualitas hidup dari pasien yang menjalani hemodialisis (Amani dkk, 2010). Dampak depresi pun tidak hanya dirasakan oleh pasien, keluarga pasien terutama pasangan hidup pasien akan sangat mudah mendapatkan depresi akibat melihat orang yang dicintai menderita, sehingga akan memengaruhi dukungan dan motivasi yang akan diberikan kepada pasien, terutama pada pasien yang menjalani hemodialisis yang harus menjalani proses cuci darah seumur hidup, sehingga banyak terjadi depresi pada pasien dan keluarganya terutama pasangan hidup pasien (Saeed, 2012).

Menurut Sadock's, James, dan Alcott, depresi merupakan salah satu dari gangguan mood yang utama. Depresi yaitu perasaan hilangnya energi dan minat, perasaan bersalah, kesulitan berkonsentrasi, hilangnya nafsu makan, dan pikiran tentang kematian atau bunuh diri.Tanda dan gejala lain gangguan mood adalah perubahan tingkat aktivitas, kemampuan kognitif, pembicaraan dan fungsi vegetatif seperti tidur, nafsu makan, aktivitas seksual dan irama biologis lainnya. Perubahan tersebut hampir selalu menyebabkan gangguan fungsi interpersonal, sosial, dan pekerjaan (Amalia dkk, 2015).

Salah satu terapi yang dapat digunakan untuk mengurangi tingkat depresi pasien gagal ginjal adalah Spiritual Emotional Freedom Technique (SEFT). Terapi SEFT dikembangkan dari Emotional Freedom Technique (SEFT), oleh Gary Craig (USA), yang saat ini sangat 
populer di Amerika, Eropa, dan Australia sebagai solusi tercepat dan termudah untuk mengatasi berbagai masalah fisik, dan emosi, serta untuk meningkatkan performa kerja. SEFT bekerja dengan prinsip yang kurang lebih sama dengan akupuntur dan akupressur. Ketiga teknik ini berusaha merangsang titik-titik kunci di sepanjang 12 jalur energi (energi meridian) tubuh yang sangat berpengaruh pada kesehatan (Zainuddin, 2012).

Terapi SEFT yang sudah dilakukan akan menimbulkan keikhlasan bagi pasien, sehingga pasien akan menerima dengan positif penyakit yang sedang dialami melalui ketabahan hati, harapan sembuh, serta mampu mengambil hikmah. Hal tersebut akan meningkatkan kualitas hidup pasien gagal ginjal, dengan indikator perbaikan pada aspek fisik, sosial, dan psikologis. SEFT dipilih untuk meningkatkan kualitas hidup karena SEFT berfokus pada peningkatan spiritual dari pasien gagal ginjal. Spiritual dan kesehatan adalah dua hal yang berkaitan. Pada penyakit yang umum sekalipun, kondisi pikiran, emosi, sikap, kesadaran, dan doa-doa yang dipanjatkan oleh atau untuk pasien sangat berpengaruh bagi kesembuhannya (Zainuddin, 2012).

\section{METODE PENELITIAN}

Jenis penelitian ini adalah penelitian kuantitatif dengan menggunakan desain pre experiment yaitu melakukan perlakuan pada satu kelompok tanpa menggunakan kelompok kontrol (Sugiyono, 2015). Tujuan penelitian adalah memberikan terapi SEFT kepada pasien GGK yang menjalani hemodialisis untuk mengurangi tingkat depresi.

Jumlah sampel penelitian adalah 10 orang. Alat untuk mengumpulkan data menggunakan kuesioner Beck Depression Inventory (BDI). Teknik analisis data menggunakan analisis univariat, bivariat (Paired $t$-test).

\section{HASIL DAN PEMBAHASAN}

\section{a. Karakteristik Responden}

Usia responden pada kelompok intervensi terapi Spiritual Emotional Freedom Technique (SEFT) sebagian besar berusia antara 55-58 tahun (40. Sebagian besar responden adalah laki-laki (90\%), dengan tingkat pendidikan lulus SLTA sederajat (30\%) dan lulus perguruan tinggi (30\%). Pekerjaan responden Sebagian besar adalah buruh (40\%), serta seluruhnya mengalami hemodialisis kurang dari 2 tahun (100\%).

\section{b. Tingkat Depresi}

Hasil penelitian tingkat depresi responden sebelum dilakukan terapi SEFT dan setelah dilakukan terapi SEFT dapat dilihat pada tabel berikut ini.

Tabel 1 Tingkat Depresi Sebelum (Pretest) dan Sesudah (Posttest) Terapi SEFT

\begin{tabular}{lcrrrr}
\hline & $\mathrm{N}$ & \multicolumn{1}{c}{ Min } & Max & Mean & SD \\
\hline Pretest & 10 & 5,00 & 45,00 & 24,6000 & 13,51707 \\
Posttest & 10 & 4,00 & 35,00 & 19,9000 & 11,03983 \\
Valid N (listwise) & 10 & & & & \\
\hline
\end{tabular}

Tabel di atas menunjukkan bahwa dari 10 responden, skor atau tingkat depresi responden sebelum dilakukan intervensi SEFT minimal adalah 5 dan tertinggi adalah 45, rata-rata skor adalah 24,6 dengan standar deviasi sebesar 13,51707. Kemudian setelah dilakukan terapi SEFT, skor atau tingkat depresi responden tersebut secara keseluruhan mengalami penurunan, yaitu skor terendah adalah 4 dan tertinggi adalah 35, rata-rata skor adalah 19,9 dengan standar deviasi sebesar 11,03983. Jadi terjadi penurunan tingkat depresi pada responden setelah diberikan terapi SEFT. 


\section{c. Perbedaan Tingkat Depresi Berdasarkan uji Paired T-test hasilnya dapat disajikan seperti pada tabel di bawah ini.}

Tabel 2 Analisis Paired T-test Pengaruh Terapi SEFT terhadap Tingkat Depresi

\begin{tabular}{llllll}
\hline Mean & Std. Deviation & Mean & t & df & Sig \\
\hline 4,70000 & 3,05687 &, 96667 & 4,862 & 9 &, 001 \\
\hline
\end{tabular}

Tabel di atas menunjukkan hasil analisis Paired T-test tentang pengaruh terapi SEFT terhadap tingkat depresi, pre test dan post test diperoleh data $p$ value $=0,001<0,05$ yang berarti terdapat pengaruh terapi SEFT terhadap tingkat tingkat deperesi.

\section{d. Usia}

Usia lanjut akan mengalami penurunan di berbagai sistem tubuh yang meliputi beberapa aspek baik biologis, fisiologis, psikologis, maupun spiritual merupakan fenomena yang kompleks dan multidimensial (Stanley, 2006 dalam Ningtyas, 2014). Menurut teori penuaan biologi, usia lanjut mengalami penurunan fungsi dan struktur atau mengalami proses degeneratif. Hal ini mengakibatkan perubahan sistem saraf pusat, antara lain perubahan gelombang otak dan siklus sirkadian.

\section{e. Jenis Kelamin}

Jenis kelamin merupakan gender yang dimiliki oleh setiap orang, pada penelitian ini responden kebetulan hampir sebagian besar adalah laki-laki, karena dari 10 repsonden hanya ada satu perempuan. Namun demikian, baik laki-laki maupun perempuan sama-sama mengalami depresi apabila menghadapi permasalahan yang berat, seperti mengindap penyakit gagal ginjal dan harus menjalani hemodialisis.

\section{d. Tingkat Pendidikan}

Semakin tinggi pendidikan seseorang akan mempengaruhi kemampuan dalam menerima informasi dan melakukan pemanfaatan terhadap pelayanan kesehatan yang ada untuk meningkatkan kualitas hidupnya (Notoatmodjo, 2013). Menurut Stuart \& Laraia (2006) dalam Sentana (2016) pengetahuan yang dimiliki, seseorang akan dapat menurunkan perasaan cemas dan depresi yang dialami dalam mempersepsikan suatu hal. Pengetahuan ini sendiri biasanya diperoleh pengetahuan dan pengalaman yang pernah dilewati individu. Kurangnya akses informasi dan pemahaman lansia terhadap kemajuan jaman termasuk kemajuan bidang kesehatan diri, hal ini dapat menimbulkan kecemasan atau depresi pada diri seseorang. Hal ini mengingat bahwa seseorang yang kurang berpendidikan seringkali kurang mampu mengendalikan dirinya (self control).

\section{e. Jenis Pekerjaan}

Jenis pekerjaan dapat mempengaruhi depresi seseorang, karena jenis pekerjaan berkaitan dengan besarnya pendapatan seseorang. Jika seseorang sedang mengalami penyakit gagal ginjal dan harus menjalani hemodialisis, sementara tidak memiliki penghasilan yang cukup untuk membiayai pengobatan penyakitnya, akan semakin cepat mengalami depresi dibandingkan dengan seseorang yang memiliki pendapatan yang cukup atau berlimpah.

Menurut Turner dan Helms (1995) seperti yang dikutip oleh Sari (2013), masa pensiun terjadi ketika individu telah berhenti dari aktivitas atau dunia kerja dan dirinya mulai menjalankan peranan baru dalam kehidupannya. Salah satu penyebab yang menjadi alasan individu dipensiunkan adalah faktor usia yang telah dirasa mulai kurang produktif.

Monks (2002) dalam Sari (2013) menambahkan bahwa individu yang telah menjalani masa pensiun akan mengalami krisis tingkat integritas diri sebagai akibat dari perubahan 
peran yang dialaminya dari individu dengan aktivitas yang padat menjadi individu dengan bebas aktivitas. Lanjut usia merupakan tahap akhir dari proses kehidupan yang dijalani setiap individu. Usia lanjut dipandang sebagaimasa kemunduran dalam segi fisik dan psikologis, masa kelemahan, dan menurunnya fungsi dan daya tahan tubuh sehingga mudahnya terserang penyakit.

\section{f. Lama Hemodialisis}

Berdasarkan lama menjalani hemodialisis pada kelompok intervensi terapi SEFT seluruhnya mengalami hemodialisis kurang dari 2 tahun (100\%). Untuk itu, pasien gagal ginjal yang menjalani hemodialisis di RSU PKU Muhamamdiyah Delanggu Klaten belum lebih dari 2 tahun. Artinya yang bersangkutan masih aktif menjalani terapi hemodialisis.

\section{Hubungan Depresi dengan Pasien Gagal Ginjal yang Menjalani Hemodialisis}

Hasil penelitian mendukung hasil penelitian Amalia dkk (2015) yang menyimpulkan bahwa ada hubungan antara tingkat depresi penyakit ginjal kronik yang menjalani hemodialisis. Hasil penelitian Rustina (2012) menunjukan hasil yang sama yaitu ada hubungan antara depresi dengan pasien gagal ginjal kronik yang menjalani hemodialisis . Depresi ringan paling banyak terjadi , kemudian depresi sedang dan depresi berat.

Depresi adalah gangguan mental umum yang menyajikan dengan mood depresi, kehilangan minat atau kesenangan, perasaan bersalah atau rendah diri, tidur terganggu atau nafsu makan, energi rendah, dan hilang konsentrasi. Masalah ini dapat menjadi kronis atau berulang dan menyebabkan gangguan besar dalam kemampuan individu untuk mengurus tanggung jawab sehari-harinya (WHO, 2011).

Menurut Kartono (2012) depresi adalah kemuraman hati (kepedihan, kesenduan, keburaman perasaan) yang patologis sifatnya. Biasanya timbul oleh; rasa inferior, sakit hati yang dalam, penyalahan diri sendiri dan trauma psikis. Jika depresi itu psikotis sifatnya, maka ia disebut melankholi. Berdasarkan beberapa pendapat diatas dapat ditarik kesimpulan bahwa depresi adalah gangguan mood, kondisi emosional berkepanjangan yang mewarnai seluruh proses mental (berpikir, berperasaan dan berperilaku) seseorang, muncul perasaan tidak berdaya dan kehilangan harapan syang disertai perasaan sedih, kehilangan minat dan kegembiraan, berkurangnya energi yang menuju kepada meningkatnya keadaan mudah lelah yang sangat nyata dan berkurangnya aktivitas.

Pada umumnya, individu yang mengalami depresi menunjukkan gejala psikis, fisik dan sosial yang khas. Beberapa orang memperlihatkan gejala yang minim, beberapa orang lainnya lebih banyak. Tinggi rendahnya gejala bervariasi dari waktu ke waktu. Menurut Institut Kesehatan Jiwa Amerika Serikat (NIMH) dan Diagnostic and Statistical manual IVText Revision (DSM IV - TR). Kriteria depresi dapat ditegakkan apabila sedikitnya 5 dari gejala dibawah ini telah ditemukan dalam jangka waktu 2 minggu yang sama dan merupakan satu perubahan pola fungsi dari sebelumnya. Gejala dan tanda umum depresi adalah sebagai berikut (Dirgayunita, 2016): (1) Gejala Fisik, seperti: a) Gangguan pola tidur; Sulit tidur (insomnia) atau tidur berlebihan (hipersomnia); b) Menurunnya tingkat aktivitas, misalnya kehilangan minat, kesenangan atas hobi atau aktivitas yang sebelumnya disukai; c) Sulit makan atau makan berlebihan (bisa menjadi kurus atau kegemukan); d) Gejala penyakit fisik yang tidak hilang seperti sakit kepala, masalah pencernaan (diare, sulit BAB dll), sakit lambung dan nyeri kronis; e) Terkadang merasa berat di tangan dan kaki; f) Energi lemah, kelelahan, menjadi lamban; g) Sulit berkonsentrasi, mengingat, memutuskan; (2) Gejala Psikis, seperti: a) Rasa sedih, cemas, atau hampa yang terus - menerus; b) Rasa putus asa dan pesimis; c) Rasa bersalah, tidak berharga, rasa terbebani dan tidak berdaya/tidak berguna; d) Tidak tenang dan gampang tersinggung; e) Berpikir ingin mati atau bunuh diri; f) Sensitif; g) Kehilangan rasa percaya diri; (3) Gejala Sosial, seperti: a) Menurunnya aktivitas dan minat 
sehari-hari (menarik diri, menyendiri, malas); b) Tidak ada motivasi untuk melakukan apapun; c) Hilangnya hasrat untuk hidup dan keinginan untuk bunuh diri.

\section{Pengaruh Terapi SEFT terhadap Tingkat Depresi Pasien Gagal Ginjal yang Menjalani Hemodialisis}

Hasil analisis Paired T-test tentang pengaruh terapi SEFT terhadap tingkat depresi, pre test dan post test diperoleh data $p$ value $=0,001<0,05$ yang berarti terdapat pengaruh terapi SEFT terhadap tingkat tingkat deperesi. Sebelum diberikan terapi SEFT diketahui tingkat depresi responden cenderung tinggi, dan setelah diberikan terapi SEFT terjadi penurunan tingkat depresi. Dengan demikian, terapi SEFT dapat menurunkan tingkat depresi para penderita gagal ginjal yang menjalani hemodilisis.

Salah satu terapi yang dapat digunakan untuk mengobati gagal ginjal kronik adalah terapi hemodialisis. Terapi hemodialisis mempunyai beberapa tujuan. Tujuan tersebut diantaranya adalah menggantikan fungsi ginjal dalam fungsi ekskresi (membuang sisa-sisa metabolisme dalam tubuh, seperti ureum, kreatinin, dan sisa metabolisme yang lain), menggantikan fungsi ginjal dalam mengeluarkan cairan tubuh yang seharusnya dikeluarkan sebagai urin saat ginjal sehat, meningkatkan kualitas hidup pasien yang menderita penurunan fungsi ginjal serta Menggantikan fungsi ginjal sambil menunggu program pengobatan yang lain (Suharyanto dan Madjid, 2015).

Pasien Gagal Ginjal Kronis (GGK) umumnya sulit untuk dapat menerima kenyataan bahwa dirinya harus menjalani hemodialisis seumur hidup dengan proses yang berjalan selama 4-5 jam setiap kali tindakan hemodialisis. Hal ini karena dapat menimbulkan kejenuhan, sehingga dibutuhkan pendamping untuk memotivasi selama menjalani terapi hemodialisis (Tezel dkk, 2011).

Pasien GGK yang menjalani hemodialisis banyak mengalami masalah psikososial, seperti depresi, kecemasan, kesepian, isolasi sosial, putus asa, dan tidak berdaya karena dirinya merasa sudah tidak ada harapam untuk sembuh dari penyakitnya. Semua hal itu merupakan masalah psikososial yang dapat meningkatkan kebutuhan pasien untuk mendapatkan perawatan holistik, yaitu termasuk perhatian dalam lingkungan dan mendapatkan dukungan dari keluarga. Jika pasien hemodialisis dirawat dan didukung sepenuhnya oleh keluarga, maka masalah psikososial ini bisa dicegah atau diminimalisir (Ahkari dkk, 2014).

Penyakit ginjal kronik memiliki dampak yang signifikan pada aspek psikologis kehidupan pasien, salah satunya akibat efek samping pengobatan, yaitu imobilitas dan kelelahan terkait ketidakmampuan untuk bekerja, disfungsi seksual, takut mati dan ketergantungan pada mesin untuk hidup mempengaruhi kualitas hidup pasien yang menjalani hemodialisis sehingga menyebabkan terjadinya depresi (Zeb dkk, 2012).

Sungguh sulit bagi seseorang untuk dapat menerima kenyataan bahwa dirinya harus menjalani hemodialisis seumur hidup dengan proses yang berjalan selama 4-5 jam setiap kali tindakan hemodialisis. Hal ini dapat menimbulkan kejenuhan, sehingga dibutuhkan pendamping untuk memotivasi selama menjalani terapi hemodialisis (Tezel dkk, 2011). Pasien hemodialisis banyak mengalami masalah psikososial, seperti depresi, kecemasan, kesepian, isolasi sosial, putus asa, dan tidak berdaya. Semua hal itu merupakan masalah psikososial yang dapat meningkatkan kebutuhan pasien untuk mendapatkan perawatan holistik, yaitu termasuk perhatian dalam lingkungan dan mendapatkan dukungan dari keluarga. Jika pasien hemodialisis dirawat dan didukung sepenuhnya oleh keluarga, maka masalah psikososial ini bisa dicegah atau diminimalisir (Ahkari dkk, 2014).

Depresi merupakan permasalahan psikiatri terbanyak pada pasien yang menjalani hemodialisis (Zeb dkk, 2012). Gejala depresi terdapat pada 30\% pada pasien yang menjalani 
hemodialisis. Gejala depresi ini ber-hubungan dengan peningkatan mortalitas dan penurunan kualitas hidup dari pasien yang menjalani hemodialisis (Amani dkk, 2010).

Kondisi afektif yang negatif pada pasien gagal ginjal juga seringkali bertumpang tindih gejalanya dengan gejala-gejala pasien penyakit ginjal kronik yang mengalami uremia seperti iritabilitas, gangguan kognitif, ensefalopati, akibat pengobatan atau akibat hemodialisis yang kurang maksimal. Pendekatan psikodinamik pada gangguan depresi adalah suatu kondisi yang berhubungan dengan hilangnya sesuatu di dalam diri manusia tersebut (Andri, 2013).

Penelitian Cwiek dkk (2017) dengan judul "Association Between Depression And Hemodialysis In Patients With Chronic Kidney Disease" menyimpulkan bahwa tingginya prevalensi depresi dan kecemasan di antara pasien dengan GGK. Selanjutnya, dikatakan bahwa pasien yang menjalani hemodialisis mengalami depresi lebih besar. Hal ini menunjukkan pentingnya pemantauan kondisi mental pasien serta perlunya memberikan perawatan psikologis yang tepat waktu untuk pasien GGK. Temuan ini menyiratkan perlunya melatih tenaga medis yang bekerja di bangsal nefrologi untuk lebih memperhatikan perilaku pasien. Bantuan psikiatris yang tepat waktu mungkin penting untuk meningkatkan kondisi mental dan kualitas hidup pasien, yang keduanya dapat berkontribusi terhadap kemanjuran perawatan utama.

Salah satu terapi yang dapat digunakan untuk menurunkan tingkat depresi pasien gagal ginjal kronik yang menjalani hemodialisis adalah terapi Spiritual Emotional Freedom Technique (SEFT). Terapi SEFT yang sudah dilakukan akan menimbulkan keikhlasan bagi pasien, sehingga pasien akan menerima dengan positif penyakit yang sedang dialami melalui ketabahan hati, harapan sembuh, serta mampu mengambil hikmah. Hal tersebut akan meningkatkan kualitas hidup pasien gagal ginjal, dengan indikator perbaikan pada aspek fisik, sosial, dan psikologis. SEFT dipilih untuk meningkatkan kualitas hidup karena SEFT berfokus pada peningkatan spiritual dari pasien gagal ginjal. Spiritual dan kesehatan adalah dua hal yang berkaitan. Pada penyakit yang umum sekalipun, kondisi pikiran, emosi, sikap, kesadaran, dan doa-doa yang dipanjatkan oleh atau untuk pasien sangat berpengaruh bagi kesembuhannya.

Spiritual Emotional Freedom Technique (SEFT) bekerja dengan prinsip yang kurang lebih sama dengan akupuntur dan akupressur. Ketiga teknik ini berusaha merangsang titik titik kunci di sepanjang 12 jalur energi (energi meridian) tubuh yang sangat berpengaruh pada kesehatan kita (Zainuddin, 2012). Berdasarkan definisi tersebut, dapat disimpulkan bahwa SEFT atau Spiritual Emotional Freedom Technique (SEFT) adalah suatu teknik terapi yang menggunakan energi tubuh atau energy meridian yang dilakukan dengan memberikan ketukan-ketukan ringan pada titik titik tertentu pada meridian tubuh, sehingga dapat mengatasi masalah fisik serta emosi.

Kelebihan terapi SEFT (spiritual emotional freedom tehnique) dibanding teknik atau metode terapi atau konseling atau training yang lain adalah (Zainuddin, 2012): (a) Mudah dipelajari dan mudah dipraktikkan oleh siapa saja; (b) Cepat dirasakan hasilnya; (c) Murah (sekali belajar bisa kita gunakan untuk selamanya, pada berbagai masalah); (d) Evektifitasnya relatif permanen; (e) Jika dipraktikkan dengan benar, tidak ada rasa sakit atau efek samping, jadi sangat aman dipraktikkan oleh siapapun; (f) Universal (bisa diterapkan untuk masalah fisik atau emosi apapun).

Terapi SEFT dapat membangkitkan impuls hipokampus (pusat memori) yang vital untuk mengkoordinasikan segala hal yang diserap indera) untuk menghasilkan Gaba (gama amino batiric acid) yang mengontrol respon emosi dan menghambat asetylcholine, serotonin dan neurotransmitter yang memproduksi sekresi kortisol, sehingga terjadi homeostasis (keseimbangan) dan memperbaiki sistem neurotransmitter yang terganggu, dan memunculkan optimisme dan pikiran-pikiran positif (Zainuddin, 2012). 
Penerapan terapi SEFT (spiritual emotional freedom technique) dalam individu merupakan media Pengembangan diri. Ini adalah bidang spesialisasi SEFT (spiritual emotional freedom technique), termasuk di dalamnya adalah penggunaan SEFT (spiritual emotional freedom technique) untuk mengatasi berbagai masalah pribadi. Berapa banyak orang yang stagnan atau terhenti pengembangan dirinya hanya karena tidak dapat mengatasi satu atau beberapa masalah pribadi. Ini bisa berupa trauma masa lalu yang terus menghantui hidup kita, kebiasaan jelek yang sukar kita tinggalkan, ketakutan untuk mengambil resiko, dan sebagainya. Berusaha mengembangkan diri dengan masih memikul beban emosi yang belum terselesaikan ibarat mengendarai mobil dengan hand rem terkunci. Bisa maju, tetapi tersendat-sendat, tidak bisa full-speed.

SEFT (spiritual emotional freedom tehnique) adalah terapi yang membantu membebaskan diri dari masalah masalah pribadi tersebut. Dengan kata lain, menyelesaikan unfinished business yang tertunda, konflik batin yang belum terselesaikan. Setelah bebas dari belenggu "penjajahan emosi", barulah dapat melangkah lebih jauh untuk mengembangkan potensi diri dengan optimal. Mengolah diri menjadi manusia paripurna (Zainuddin, 2012).

\section{SIMPULAN DAN SARAN Simpulan}

Karakteristik pasien gagal ginjal yang menjalani hemodialisis di RSU Muhammadiyah Delanggu Klaten yang dijadikan responden penelitian dapat dijelaskan sebagai berikut: (a) Usia pasien sebagian besar berusia antara 45-58 tahun (70\%), dan termasuk usia pertengahan memasuki periode lanjut usia; (b) Berdasarkan jenis kelamin, hampir seluruhnya adalah laki-laki (90\%); (c) Tingkat pendidikan pasien sebagian besar lulus SLTA sederajat (30\%) ; (d) Jenis pekerjaan pasien sebagian besar adalah buruh $(40 \%)$, ; (e) Seluruh pasien menjalani hemodialisis dalam kurun waktu kurang dari 2 tahun (100\%).

Terapi SEFT dapat meneurunkan tingkat tingkat deperesi pasien gagal ginjal yang menjalani hemodialisis, yang dibuktikan dari hasil uji Paired T-test antara skor pre test dan post test diperoleh angka $p$ value $=0,001<0,05$.

\section{Saran}

Dengan memperhatikan hasil penelitian ini, maka ada beberapa saran yang dapat disampaikan, yaitu: terapi SEFT dapat dijadikan sebagai praktek mandiri perawat dalam mengatasi masalah psikososial yang dialami oleh pasien dan keluarga sehingga dapat meningkatkan kulitas hidup pasien.

Penelitian lebih lanjut dapat dilakukan dengan yang tertarik mengkaji manfaat terapi SEFT dengan sampel dan metode penelitian yang berbeda, serta menambahkan variabel bebas yang lainnya, untuk melengkapi informasi tentang berbagai manfaat tentang SEFT seperti untuk menurunkan stres, mengurangi gejala kurang tidur, dan lain-lain.

\section{DAFTAR PUSTAKA}

Ahkari S, Moshki M, Bahrami M. 2014. The relationship between social support and adherence of dietary and fluids restrictions among hemodialysis patients in Iran. Journal of Caring Science. 2014; 3(1):11-9.

Amalia, F., Nadjmir, dan S. Azmi. 2015. Gambaran Tingkat Depresi pada Pasien Penyakit Ginjal Kronik yang Menjalani Hemodialisis di RSUP DR. M. Djamil Padang, Jurnal Kesehatan Andalas. 2015; 4(1).

Andri. 2013. Gangguan psikiatrik pada pasien penyakit ginjal kronik. Bagian Psikiatri, Fakultas Kedokteran Universitas Kristen Krida Wacana. Jakarta, Indonesia. 2013; 40(4). 
Cengic B, Resic H. 2010. Depression In Hemodialysis Patients. Bosnian Journal Of Basic Medical Sciences (Supplement 1): 2010; S73-S78.

Darwis Y. Masalah Pelayanan Gangguan Kesehatan Jiwa Di Rumah Sakit Umum [Internet]. Diambil dari http://id.scribd.com/doc/51502535/ Gangguan-Jiwa-di-RSU-dr-YulizarSp-KJ. Agustus 2018.

Dirgayunita, Aries. 2016. Depresi: Ciri, Penyebab dan Penangannya. Journal An-nafs: Kajian dan Penelitian Psikologi. Vol. 1 No. 1 Juni 2016: 1-14.

Hakam. 2011. Pengaruh SEFT Terhadap Penurunan Nyeri Pasien Kanker Rahim Stadium II di RS Ciptomangunkusumo. Tesis. Jakarta: FKUI.

Harrison. 2012. Prinsip-prinsip Ilmu Penyakit Dalam. Jakarta: Jakarta: EGC.

Hickie, B. 2011. An Approach to Managing Depression in General Practice: Long Term Management of Patients with Depression; An Essential Skill for All General Practitioners, MJA, 173: 106-110.

Infodatin. 2017. Situasi Penyakit Ginjal Kronis. Jakarta Selatan: Pusat Data dan Informasi Kementerian Kesehatan RI.

Khalil A. Amani, Lennie A. Terry, Frazier K. Susan. 2010. Understanding the negative effects of depressive symptoms in patients with ESRD receiving hemodialysis. Nephrologi nursing journal.2010;37(3):289-308.

Notoatmodjo, Soekidjo. 2015. Metodologi Penelitian Kesehatan. Jakarta: PT Rhineka Cipta.

Pernefri, 2012. Naskah lengkap: workshop \& impresium nasional peningkatan pelayanan hemodialisis, penyakit ginjal dan aplikasi indonesia renal registry joglosemar. Jakarta: Perhimpunan Nefrologi Indonesia.

Republika, 2018. 36 Juta Warga Dunia Meninggal Gagal Ginjal [internet]. Diambil dari http://www.republika.co.id/berita/gaya-hidup/infosehat, Agustus 2018.

Rustina, 2012. Gambaran Tingkat Depresi Pada Pasien Gagal Ginjal Kronik Yang Menjalani Hemodialisis Di RSUD Dr. Soedarso Pontianak, Program Studi Pendidikan Dokter, Fakultas Kedokteran Universitas Tanjungpura Pontianak 2012. Naskah Publikasi. Program Studi Pendidikan Dokter Fakultas Kedokteran Universitas Tanjungpura Pontianak 2012: 1-14.

Saeed Z, Ahmad AM, Shakoor A. 2012. Depression in patients on hemodialysis and theire caregiver. Departement of nephrology and psychiatry. 2012;23(5):946-52.

Sari, D.P. 2013. Pengaruh Dukungan Keluarga Terhadap Psychological Well-Being Pada Masa Pensiun. Jurnal Psikologi Pendidikan dan Perkembangan, Vol. 2 No. 03 Desember 2013,Pp.194-205.

Sentana, A.D. 2016. Analisis Faktor-Faktor yang Mempengaruhi Tingkat Kecemasan Keluarga Pasien yang Dirawat di Ruang Intensif Care RSUD Provinsi NTB Tahun 2015. Jurnal Kesehatan Prima, Vol. 10 No. 2, Agustus 2016, Pp.1694- 1708.

Sudoyo AW, Setiyohadi B, Alwi I. 2010. Buku Ajar Ilmu Penyakit Dalam, (5th ed). Jakarta: Interna Publishing.

Sugiyono. 2015. Statistika untuk penelitian. Bandung: Penerbit Alfabeta.

Tezel A, Karabulutlu E, dan Sahin O. 2011. Depression and perceived social support from family in Turkish patients with chronic renal failure treated by hemodialysis. J Res Med Sci. 2011;16(5):666-75. 
WHO. 2011. Programme on Mental Health WHOQOL User Manual. Switzerland: Department of Mental Health, World Health Organization.

Wiek, A., M. Czok, B. Kurczab, K.Kramarczyk, K. Drzyzga \& K. Kucia. 2017. Association Between Depression And Hemodialysis In Patients With Chronic Kidney Disease.

Psychiatria Danubina, 2017; Vol. 29, Suppl. 3, pp 499-503.

Zainuddin, A.F. 2012. Spiritual emotional freedom technique (SEFT). Jakarta: Afzan Publishing.

Zeb, S., A.M. Aizaz, S. Abdul, G. Farkhanda, K. Shumaela. 2012. Depression in patients on hemodialysis and their caregiver. Departement of nephrology and psychiatry, Federal sheikh zayed postgraduate medical institute, Lahore, national health research complex, Federal sheikh zayed postgraduate medical institute, Lahore, Pakistan. 2012;23(5):94652. 